\title{
Measuring Spatial Cluster for Leading Industries in Surakarta with Exploratory Spatial Data Analysis (ESDA)
}

\author{
\begin{tabular}{|c|}
\hline Muhammad Arif, Didit Purnomo \\
Faculty of Economics and Business, Universitas Muhammadiyah Surakarta \\
Corresponding Author: arif@ums.ac.id; dp274@ums.ac.id \\
\hline
\end{tabular}
}

Received: May 2017; Accepted: June 2017

\begin{abstract}
This paper concentrates in identifying the location and assessing the economic clusters of leading industries in Surakarta City, Indonesia based on the number of units and labor absorption by using the Exploratory Spatial Data Analysis (ESDA). In association with the first objective, ArcGis was employed to find out how the concentration of leading industries in Surakarta was formed. The analysis revealed that the industries in Surakarta City have a propensity to be remote from downtown and concentrated in the northern part of the city. The second objective was revealed by performing the Moran's index on GeoDa software to determine the spatial autocorrelation among the observed areas as the basis in finding the leading industrial cluster. The analysis indicated that all leading industries have relatively low Moran's index meaning there was show small autocorrelation between leading industry in Surakarta. These results have been confirmed by the LISA method to reveal the areas having spatial autocorrelation for each industrial sector.
\end{abstract}

Keyword: Economic clusters, Exploratory Spatial Data Analysis (ESDA), Moran's index, spatial autocorrelation, leading industries

JEL Classification: R12, C38

\section{Introduction}

The development of economics as a discipline particularly at the regional level has made significant progress in the last decade of the past century, the regional approach has frequently been linked to the policies of regional development in the attempts to create economic effectiveness and efficiency (Friedmann, 2005). One of the most significant approaches in facilitating regional growth is the economic clusters (Yang, Hao, \& Cai, 2015). Such approach has been simultaneously employed in a broad spectrum to devise the spatial linkages of regional economic activities from agriculture to high-tech industries or consumer service sectors to business and finance, in which the classic goal is to realize scale economies and to minimize transport costs at once (Krugman, 1991).

Spatial-based analysis becomes the foundation of economic clusters in carrying out optimal economic functions in which there are two basic concepts in this perspective. First, the classical economists assume that the transfer of economic activities occur if the local scale activities of each region are complementary to one another. Second, the modern economists, e.g. Bertil Ohlin, who perceive that spatial concentration involves the characteristics and function of regional correlation in the world so that economic activities can be global-scale and encompass a wide range of global distribution of goods (Wheeler \& Muller, 1986). Both concepts perceive that the 


\section{Jurnal Ekonomi Pembangunan, 18 (1), 2017, 64-81}

pattern of economic activities requires space to move, while the implication is the structural transformation of spatial changes, referring to the term propounded by Yunus, the change of land use is mentioned as spatial transformation, which is essentially the articulation of human activities on a plot, the change eventually evolves into a magnetic force which attracts individuals and institutions oriented to the ease of grouping and having activities in the region (Yunus, 2000). As an example, the transformation of a sub-urban area in the coastal area of San Francisco where it was originally a military camp which is turned into the Silicon Valley Industrial district after the Second World War and has since developed into an industrialization center in the US. Similarly, the Stanford Industrial Park which is built in suburban agricultural area of Britain, is currently still a major area of industrial development in Britain (Berdahl et al., 1997)

In Indonesia, the economic clusters are mainly located in Java island which concentration forms bipolar pattern, the first pattern located at the western tip of Java island namely Jabotabek covering (Jakarta, Bogor, Tangerang, Bekasi) and Bandung, and at the eastern tip including Gerbangkertosusila (Gresik, Bangkalan, Mojokerto, Surabaya, Sidoarjo, Lamongan) (Kuncoro, 2000). Central Java situated in the middle area between the two poles serves as a connector that links them, but eventually this region endures the spread effects of the industrialization activities of the two poles. The core center of Central Java development is located in Semarang and supported by hinterlands. These hinterlands are divided into 8 (eight) corridors and one of the important corridors of Central Java is Subosukowonosraten (Surakarta, Boyolali, Sukoharjo, Wonogiri, Sragen and Klaten) with the core of activities is centered in Surakarta.
The fast-track growth theory (turnpike) explicates that each region needs to comprehend the sectors or commodities that have great potential and can be developed quickly, both due to their natural potential and their competitive advantage to progress. (Deichmann, Lall, Redding, \& Venables, 2008) suggested that the most dominant sector as the most effective engine driving the economic growth in developing countries is the industrial sector. Based on this understanding, the leading industries should obtain specialconcern in the economic development of a region, particularly in developing countries, since this sector can serve as groundwork in the establishment and economic growth of a region.

The determination of Surakarta City as the center and economic node is the rise of the movement of Development Area (Wilayah Pengembangan/WP) 4, making this city has a strategic role for the economic growth of Central Java Province (Arif \& Utomo, 2016). The geographical and administrative position of Surakarta is perceived as ideal as the foundation in supporting the national economic activities in the central corridor, and as the impact, the economic growth, activity, and physical growth of Surakarta City rapidly progress. In addition, Surakarta City is one of the cities having huge potential as the center of economic activities, powerful industrial centers at the upstream that are supported by the markets with national and international market share at the downstream. Consequently, those two sectors become dominant in the preparation of Local Government Budget $(A P B D)$ as well as their significant role as driving force in the regional economy. At regional scale, Surakarta has relatively high number of considerable potential export-scale industries, as mentioned in Table 1. 
Avalaible online at http://journals.ums.ac.id

Jurnal Ekonomi Pembangunan, 18 (1), 2017, 64-81

Table 1 Production Value Based on Industrial Classification in Surakarta City on the basis of Current Pricing (Percent)

\begin{tabular}{lcc}
\hline \multicolumn{1}{c}{ Sector } & $\begin{array}{c}\text { Production } \\
\text { Value } \\
\text { (in thousands) }\end{array}$ & $\begin{array}{c}\text { Sector } \\
\text { Contribution } \\
\text { ( \%) }\end{array}$ \\
\hline Food and Beverages & $90,852,476$ & $5.4 \%$ \\
Tobacco Manufacturing & 842,725 & $0.1 \%$ \\
Textile & $143,110,910$ & $8.6 \%$ \\
Garment & $364,633,106$ & $21.8 \%$ \\
Leather and Leather Products & $77,840,905$ & $4.7 \%$ \\
Wood, Wood Products, Cane Ware & $144,138,380$ & $8.6 \%$ \\
Paper and Paper Products & $333,046,528$ & $19.9 \%$ \\
Publishing, Printing and Reproduction & $138,812,242$ & $8.3 \%$ \\
Chemical and Chemical Products & $295,888,623$ & $17.7 \%$ \\
Rubber and Rubber Products & $81,766,857$ & $4.9 \%$ \\
Total & $1,670,932,752$ & $100 \%$ \\
\hline
\end{tabular}

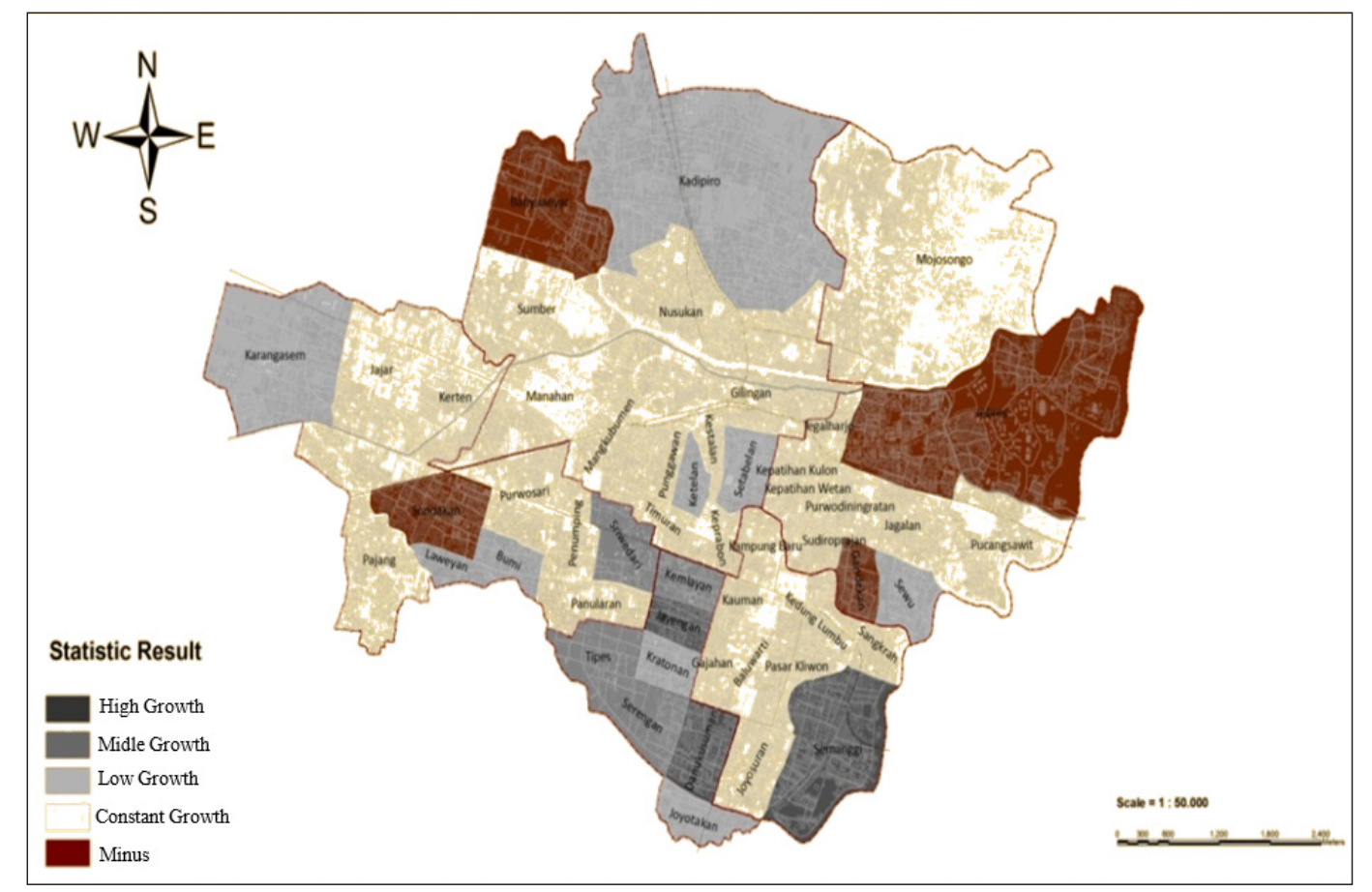

Figure 1 Spatial-based Industrial Sector Growth of Surakarta City

Source: (Arif \& Soeratno, 2015)

In general, the industrial sector of Surakarta grew by $7 \%$ in the period of $1993-2011$ where the high intensity of industry was concentrated in Kelurahan Semanggi, Pasar Kliwon Sub- district, in which in adjacent to Serengan Subdistrict. Hence, it can be assumed that the industrial development of Surakarta City is directed to Serengan Sub-district as supported 
by its correlation with Pasar Kliwon Sub-district (illustration is presented in Figure 1) (Arif \& Soeratno, 2015)

According to (Arif \& Utomo, 2016), the leading industries in Surakarta can be classified into 5 (five) sectors. Those industrial sectors are food and beverages, textile and textile product, garment, printing, and furniture. The final result of this study is to assess and detect the formation of the major industrial clusters in Surakarta based on location and direction of development by using Geographic Information System (GIS) analysis that is improved with Moran's Index, Moran Scatter Plot, and spatial autocorrelation (LISA) cluster map in assessing the concentration of the leading industries' labor force in Surakarta.

\section{Research Methods}

The methodology of this study was the secondary data research designs of the industry survey (survei industri) and regional statistics in figures published by the Central Bureau of Statistics of Surakarta (Badan Pusat Statistik Kota Surakarta). This study consisted of three stages in which Exploratory Spatial Data Analysis (ESDA) model was employed as the approach for all stages. The first stage was to determine the spatial concentration pattern of major industrial units in Surakarta City. At this stage, the analysis was done by using ArcGis analysis tool to map the concentration pattern. The second stage was to determine the spatial cluster form and value of respective leading industries in Surakarta City, which was done by calculating the spatial autocorrelation value of labor absorption of respective industry by using Moran's Index method. The third stage was to determine the labor concentration spatial pattern of leading industries in Surakarta City. The approach used in this stage was Local Moran statistics (LISA significance maps) method with GeoDa analysis tool.

\subsection{Exploratory Spatial Data Analysis (ESDA)}

Exploratory Spatial Data Analysis (ESDA) is exploration of a set of spatial data in different methods to gain a comprehensive understanding of the phenomenon under investigation in order to make better decisions on issues related to the data. ESDA is a collection of techniques to explain and describe (visualization) spatial distribution, identify the location or spatial outlier, and determine spatial association patterns (Anselin, Syabri, \& Kho, 2006). The ESDA concept can be used to analyze data in a variety of methods, in prior to form an ESDA range for a deeper understanding of the phenomenon being analyzed hence decisions are made based on more accurate data (Smith, Goodchild, \& Longley, 2015). In this study, spatial analysis was conducted using a combination of ArcGis and GeoDa software.

\subsection{Spatial Autocorrelation Analysis on Leading industries in Surakarta City}

\section{a. Global Moran's I}

According to (Anselin, 2003) Moran's Index is a spatial analysis used to determine the spatial autocorrelation between observation locations for each attribute in an area as a whole, so it can be determined whether the observed data forms clusters or not. The index is formulated as follows:

$$
I=\frac{N}{\sum_{i} \sum_{j} W_{i j}} \times \frac{\sum_{i} \sum_{j} W_{i j}\left(y_{i}-\bar{y}\right)\left(y_{j}-\bar{y}\right)}{\sum_{i}\left(y_{i}-\bar{y}\right)^{2}}
$$

or

$$
\mathrm{I}=\frac{\mathrm{N}}{\sum_{\mathrm{i}=1}^{\mathrm{N}} \sum_{\mathrm{j}=1, j \neq 1}^{\mathrm{N}} w_{\mathrm{ij}}} \times \frac{\sum_{i=1}^{N} \sum_{j=1}^{N} z_{i} w_{i j} z_{j}}{\sum_{i=1}^{N} z_{i}^{2}}
$$




\section{Jurnal Ekonomi Pembangunan, 18 (1), 2017, 64-81}

Where, $\mathrm{N}$ unit is the attribute value of each unit, $i$ is $y_{i}$, and $w_{i j}$ is weight (or connectivity) for units $i$ and $j$. The expected value from Moran's $\mathrm{I}$ is $-1 /(\mathrm{n}-1)$, and its interpretation is similar to the correlation coefficient of moment product. Informally, +1 denotes strong positive spatial autocorrelation (i.e. the same value grouping), 0 denotes a randomly spaced sequence, and -1 denotes a strong negative spatial autocorrelation (checkerboard pattern).

\section{b. Moran Scatter Plot}

Moran Scatter Plot is the method to determine the cluster value or autocorrelation value of the data. This method is relatively simple and yet very informative since it is presented in visual form. The $\mathrm{X}$ axis of the scatter plot represents the standardized $\mathrm{Z}$ values of variable (that is, they have been standardized to their $\mathrm{Z}$ scores, with a mean of zero, and a standard deviation of 1.) The $\mathrm{Y}$ axis represents the standardized values of the neighboring values around the point of interest that is the lagged values. These are calculated according to the spatial weights matrix that based on the specify variables. So, for instance, if a contiguous spatial weights matrix is specified, with a first order queen contiguity, the value of the y axis represents the mean value of the variable for all of the areas that share a border with the area of interest.

A Moran Scatter Plot is divided into four quarters, which, clockwise from top-right represent the values that are: High values surrounded by High values, High values surrounded by Low values, Low values surrounded by Low values and Low values surrounded by High values. A positive slope indicates positive spatial autocorrelation (high values clustered with high, low clustered with low), while a negative slow indicates negative spatial autocorrelation (low values clustered with high, high values clustered with low).

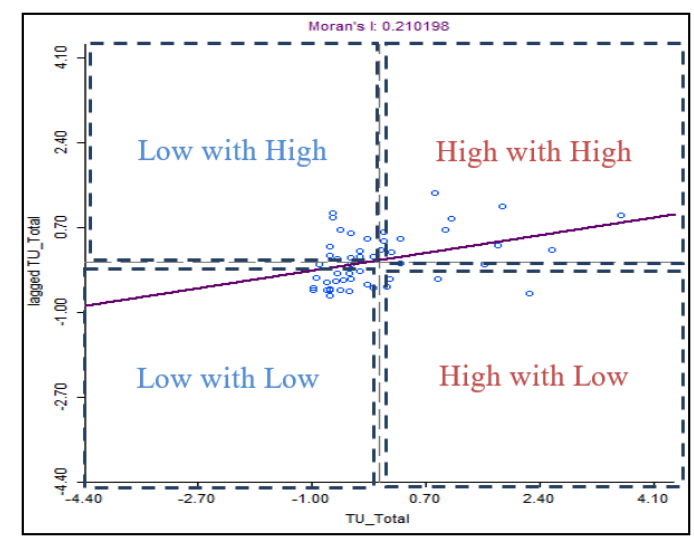

Diagram 1 Moran's Index and Moran Scatter Plot

\section{c. Local Moran's I statistics (LISA)}

Local spatial autocorrelation statistics provide a measure, for each unit in the region, of the unit's tendency to have an attribute value that is correlated with values in nearby areas. This computes a measure of spatial association for each individual location. The Local Moran's I statistic for spatial association is given as:

$$
I_{i}=\frac{x_{i}-\bar{X}}{S_{i}^{2}} \sum_{j=1, j \neq i}^{n} w_{i j}\left(x_{i}-\bar{X}\right)
$$

where $\mathrm{x}_{i}$ is an attribute for feature $\mathrm{i}$, is the mean of the corresponding attribute, $w_{i, j}$ is the spatial weight between feature $i$ and $j$, and:

$$
S_{i}^{2}=\frac{\sum_{j=1, j \neq i}^{n} w_{i j}}{n-1}-\bar{X}^{2}
$$

with $\mathrm{n}$ equating to the total number of features. The $z_{I_{i}}$ - score for the statistics are computed as:

$z_{I_{i}}=\frac{I_{i}-E\left[I_{i}\right]}{\sqrt{V\left[I_{i}\right]}}$

where:

$E\left[I_{i}\right]=-\frac{\sum_{j=1, j \neq i}^{n}}{n-1}$

and

$V\left[I_{i}\right]=E\left[I_{i}^{2}\right]-E\left[I_{i}\right]^{2}$ 


\section{Results And Discussion}

Surakarta City is an urban area that becomes the node of several hinterland areas. As a result, Surakarta is the core of development that turns into a resurrection for the areas adjacent to this city. As the theory of the regional economy on growth center, it is mentioned that the central region of growth is the center of economic activities where a lot of goods and services are concentrated and form an economic activity. As a consequence, magnetic force occurs that it attracts individuals or institutions which orientation is to support their activities, so this area becomes densely populated in line with their activities (Yunus, 2000).

\subsection{Leading Industries in Surakarta City}

The analysis results of leading industries in Surakarta City are summarized in Table 2, which is based on the findings of (Arif \& Utomo, 2016). The findings of the study claimed that at regional scale, Surakarta possesses 5 (five) leading industries in Central Java. They are Food and beverages, Textiles and textile products, Garment, Printing, and Furniture industries.

Table 2 Analysis of Leading Industries in Surakarta City

\begin{tabular}{lccc}
\hline \multicolumn{1}{c}{ Sector } & $\begin{array}{c}\text { Number Of } \\
\text { Company }\end{array}$ & $\begin{array}{c}\text { Labor Force } \\
\text { (Person) }\end{array}$ & $\begin{array}{c}\text { Value Added } \\
\text { (Rp. 000) }\end{array}$ \\
\hline $\begin{array}{l}\text { Food and Beverages } \\
\text { Textile and Textile }\end{array}$ & 463 & 3.073 & 227.354 .000 \\
Products & 376 & 4.831 & 256.350 .000 \\
Garment & 219 & 2.067 & 941.787 .902 \\
Printing & 198 & 1.543 & 287.796 .000 \\
Furniture & 132 & 839 & 53.660 .306 \\
Source: Surakarta dalam Angka, data of several years (analyzed).
\end{tabular}

\subsection{Leading Industries Spatial Concentration in Surakarta City}

The results of the analysis in Figure 2 were generated based on the number of sub-districts with industrial units that produce prime products in Surakarta City with the analysis unit of Desal Kelurahan (Village). The picture indicates are 4 (four) areas with very high concentration, namely: (1) Mojosongo and Jebres, at Jebres Subdistrict, there are 182 units of leading industries, dominated by food and beverages industry and furniture industry; (2) Laweyan and Pajang, Laweyan Sub-district, which has an excellent spatial concentration of leading industries, there are 158 units dominated by garment industry and food and beverages industry; (3) Tipes, Serengan Sub-district, which is classified in areas with very high industrial concentration since there are 80 units dominated by the garment industry; (4) Semanggi, Pasar Kliwon Sub-district, the leading industrial sector in this area is dominated by food and beverages industry, garment industry and textile industry, with a total of 63 units.

Furthermore, there are 3 (three) districts are classified in high concentration, namely: Sondakan, Laweyan District; Nusukan and Kadipiro, Banjarsari Sub-district; and Danukusuman, Serengan Sub-district. Spatially, those areas classified in high concentration industry have geographical connection with very high concentration area, except Tipes and Semanggi. In addition, the industries in those areas are relatively similar hence it is highly possible that the emergence of industrial clusters is affiliated with one another. Based on the results of the analysis in Figure 2, it indicates 


\section{Jurnal Ekonomi Pembangunan, 18 (1), 2017, 64-81}

that the concentration of areas with leading industries tends to cluster in the north and south of Surakarta City, while the middle area is merely categorized in medium and low group. It explains the reason the middle area of Surakarta City is not an industrial area.

Figure 3 explicates that the highest concentration of leading industrial labor is situated in the area of Kerten and Laweyan, Laweyan Sub-district, then spread over the surrounding areas such as Pajang and Sondakan. The northern part of Surakarta City, i.e. Kadipiro, Mojosongo and Jebres, as well as Semanggi, Danukusuman and Tipes are classified in high concentrations, while the central area of the city is clustered in a medium-low classification. However, if it is linked to the results of analysis on leading industrial units of Surakarta City (Figure 2), Kerten is not included in the area with high category leading industrial unit but it has the highest labor concentration. Thus, it shows that there located a large scale and labor-intensive industry in Kerten.

Based on the findings of the analysis presented in Figures 2 and 3, it stated that: (1) the areas with Very High and High criteria based on the analytical criteria are situated on the border or directly adjacent to the hinterland of Surakarta City, instead of the center of the city that has lower concentration; (2) there are industrial concentrations clustered in the northern and southern parts of Surakarta City based on industrial units and labor of the leading industries in Surakarta City, which indicates the existence of clusters of several industrial sectors in those areas. To support these statements, an analysis of the area concentration was carried out on each of the industrial units.

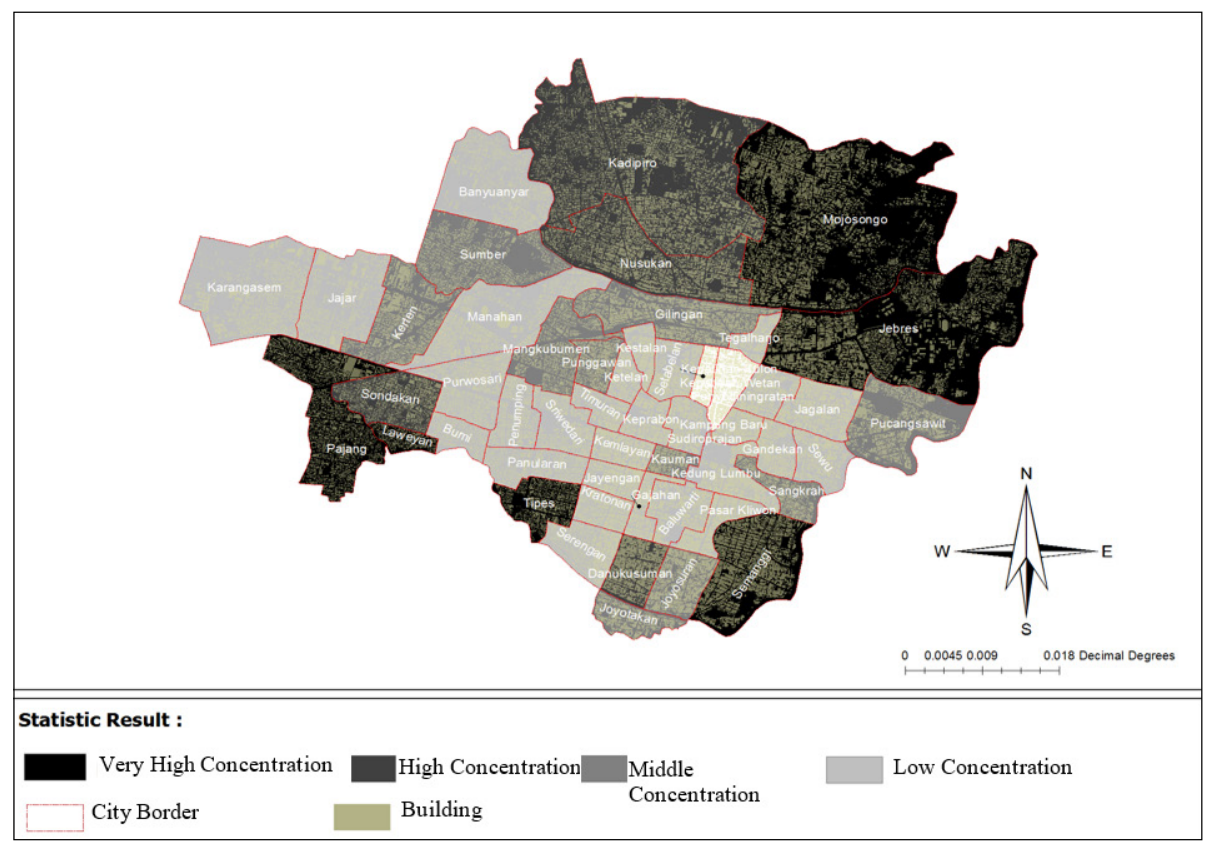

Figure 2 Leading industries Spatial Concentration Based on Industrial Units in Surakarta City 
Jurnal Ekonomi Pembangunan, 18 (1), 2017, 64-81

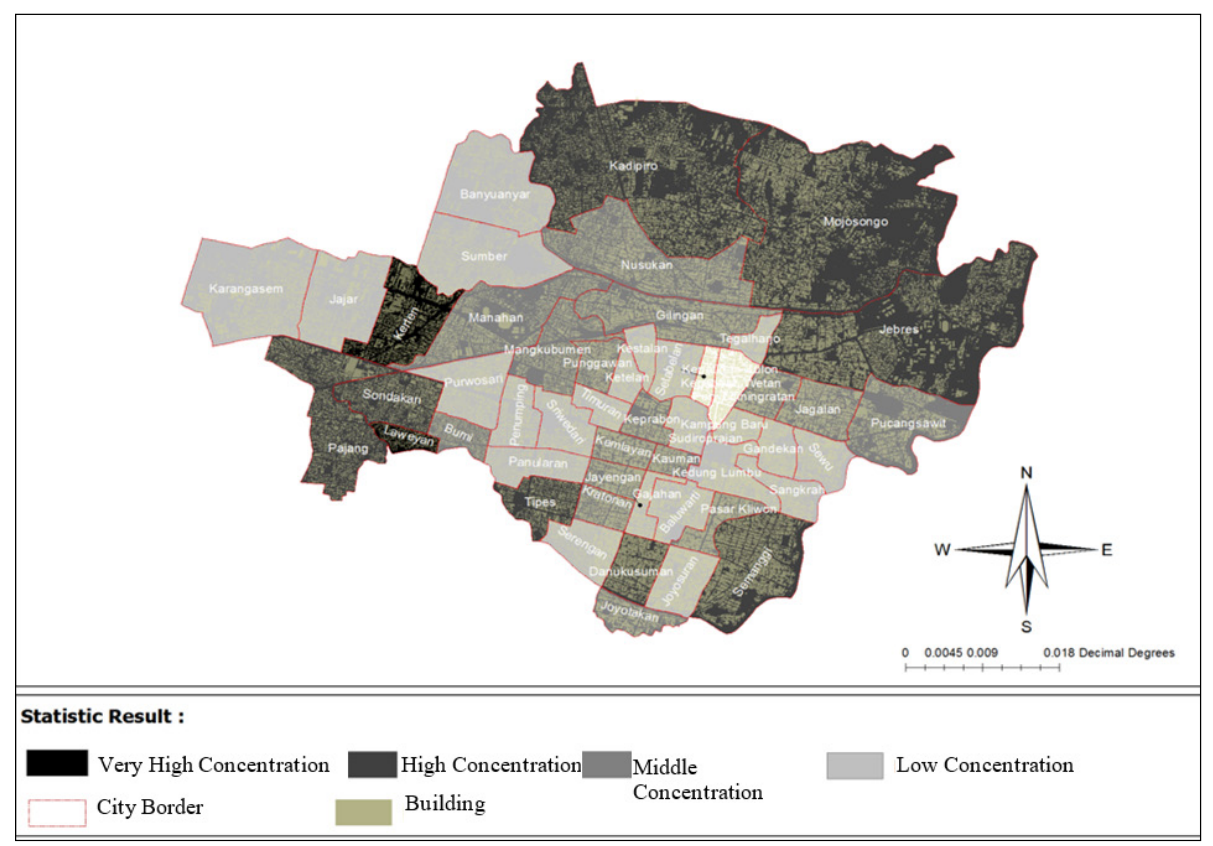

Figure 3 Leading industries Spatial Concentration Based on Labor Force in Surakarta City

\subsection{Food and Beverages Industry}

The food and beverages industries in Surakarta City developed significantly during the period of observation. In fact, this industry is the largest industrial sector based on the number of companies in compared with other leading industries. There are 463 companies are engaged in this sector with the employment of 3,073 workers. Furthermore, they produce value added approximately of Rp227,354,000,000.

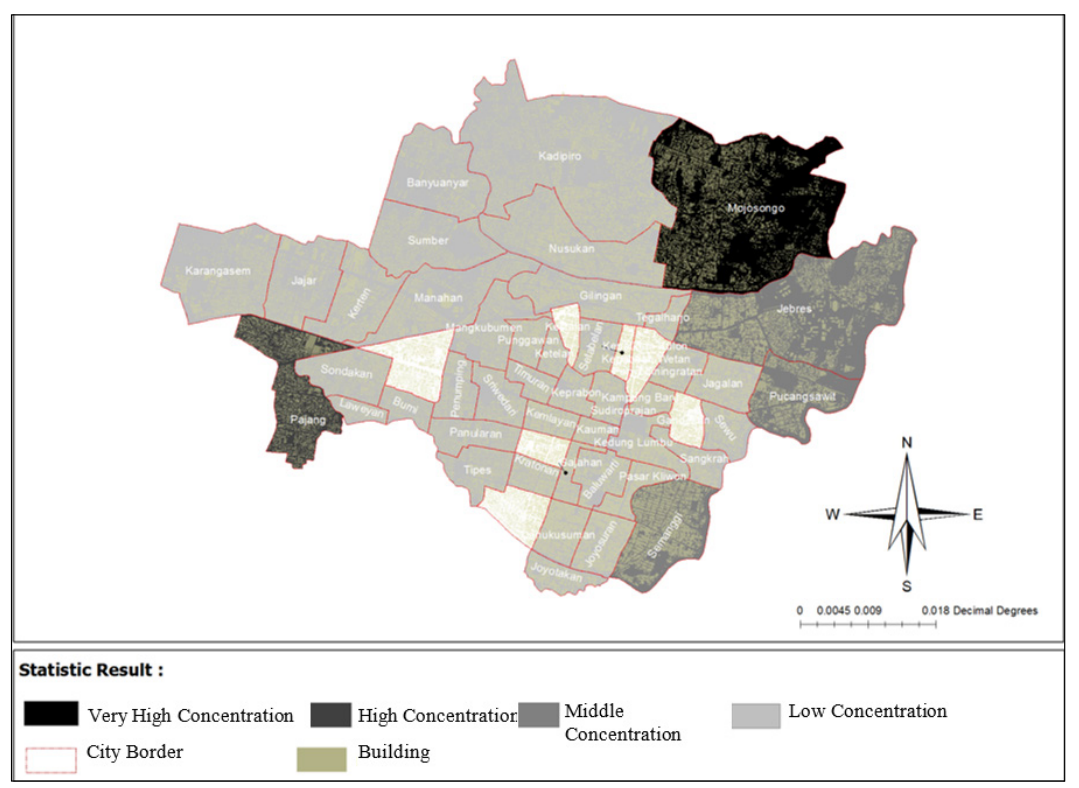

Figure 4 Spatial Distribution of Food and Beverage Industrial Units in Surakarta City 
3.4 Moran's Index and Moran Scatter Plot of Food and Beverages Industrial Sector in Surakarta City

In this study, analysis of Moran's Index and Moran Scatter Plot was done using GeoDa software that developed by Anselin. The data used in spatial weighting matrix was the coordinate location of each observation area. The results of the Moran analysis on the food and beverages industries in Surakarta City are presented in Diagram 2, the points spread among the quadrants I, II, III, and IV showing the state of quadrant at the observation area. The areas included in quadrant I are: Pajang in Laweyan Sub-district; Jebres sub-district covering Mojosongo, Jagalan and Jebres; and Banjarsari Sub-district that located in Nusukan. The areas are classified into high category, meaning they have high concentration of employment of food and beverages industries.

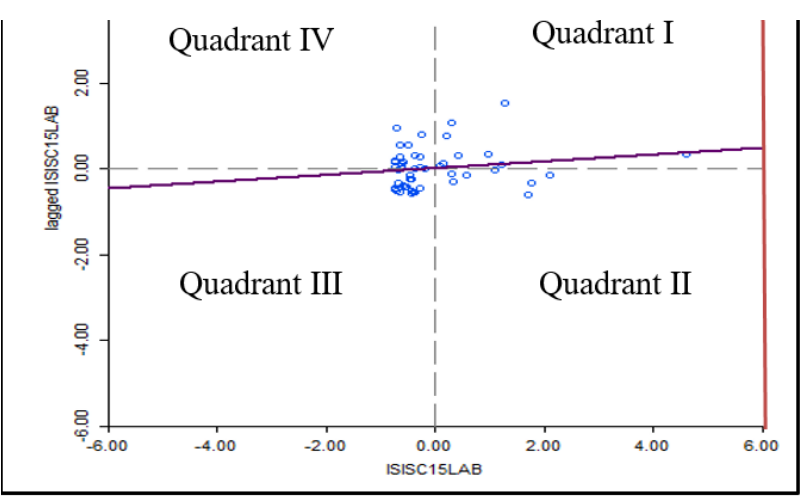

Diagram 2 Moran's Index and Moran Scatter Plot of

Food and Beverages Industry in Surakarta City

Other areas included in quadrant II, III and IV are areas with lower observation values in compared with quadrant I, thus they can be classified as areas without any labor spatial concentration of food and beverages industrial sector in Surakarta. Results of Moran's index calculation indicated a value of 0.0773723 , and in the range of $0<\mathrm{I} \leq 1$. It shows that in Surakarta, food and beverages industry has positive spatial autocorrelation even though the value is very low, since it is near to the origin value (0). Therefore, it can be concluded that the dispersion of labor in food and beverages industry among units of observation in Surakarta City has dissimilar values, which explicates the food and beverages industrial sector indicates low spatial clusters, or in other words, only small portion from the entire areas of clusters/concentrated observation units.

\subsection{Local Spatial Autocorrelation (LISA) Map Cluster of Food and Beverages Industry in Surakarta City}

This analysis describes the areas within the observation units that has have the same correlation value based on the $\mathrm{Z}$ score combination with the Moran's Index value, hence it can determine the areas with high value and those with low value of observation units. The result of LISA analysis in Figure 5 demonstrates that Kadipiro, Nusukan and Jebres are areas with high spatial autocorrelation while Penumping, Panularan and Kratonan areas are identified as areas with low spatial autocorrelation. Based on the findings and by referring to analysis of Moran's index and Moran scatter plot, hence it can be concluded that the scheme of food and beverage industry clusters in Surakarta City is formed with the core, which covers Kadipiro, Nusukan and Jebres 


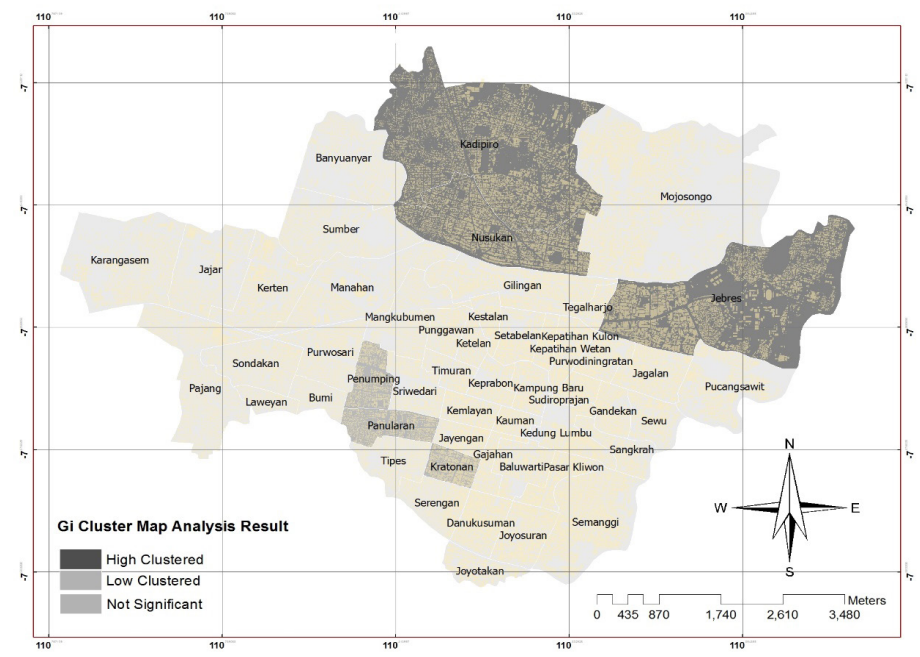

Figure 5 Local Spatial Autocorrelation of Food And Beverages Map Cluster

The survey data on industries in Surakarta City carried out by Industry and Trade Office (Disperindag) of Surakarta was used as the basis of this study. It indicates that Jebres Sub-district produces processed foods of tofu, tempe, baking and snacks where most of the labor of these food and beverages sub-sectors is absorbed in tofu- tempe production. The comparison of the data with the results of this study concluded that Jebres is an area where there are clusters or centers of food and beverages industry with mainstay products of tofu and tempe, which is highly concentrated in Kelurahan Jebres.

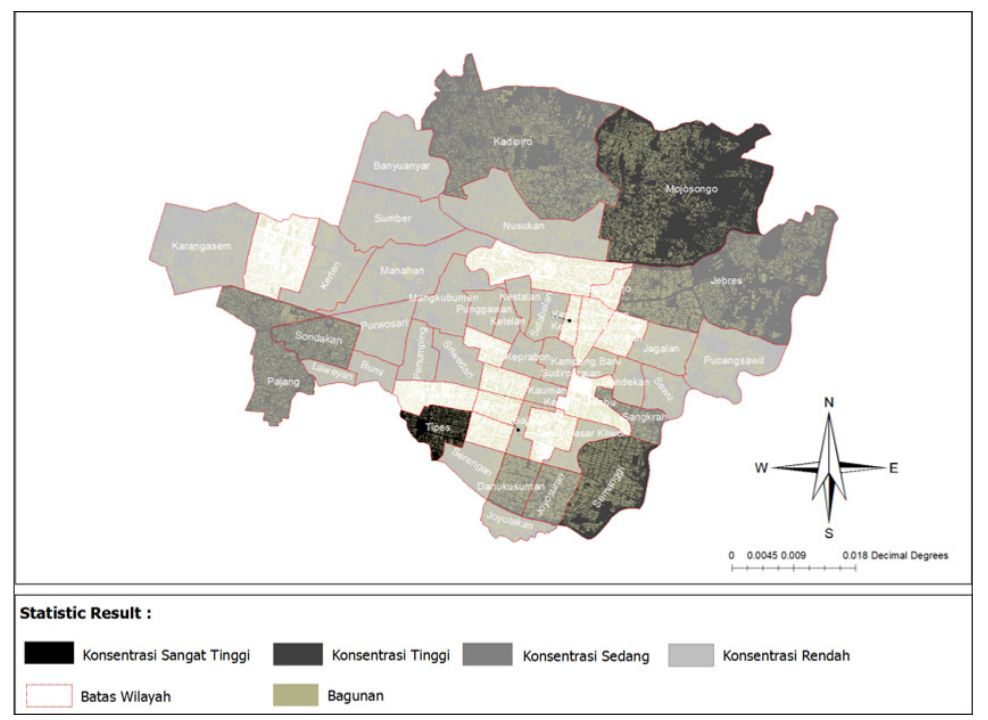

Figure 6 Spatial Distribution of Textile and Textile Products Industry Units in Surakarta City

3.6 Textile and Textile/Multifarious City. Based on Table 3, this sector has capacity Products Industry

Textile and textile/multifarious products are the to accommodate 4,831 workers or approximately industries that absorb the most labor in Surakarta $40 \%$ of all labor of the leading industrial sectors in Surakarta. The analysis of the concentration 


\section{Jurnal Ekonomi Pembangunan, 18 (1), 2017, 64-81}

of textile industry units and their derivatives as demonstrated in Figure 6 indicates the spatial distribution pattern of this industry is similar to the dispersion of food and beverages industry, which is merely concentrated at some points where the highest concentration or dispersion of textile and textile products industry is identified in Tipes.

\subsection{Moran's Index, Moran Scatter Plot} and Local Spatial Autocorrelation (LISA) Map Cluster of Textile and Textile Products Industrial Sector in Surakarta City

The result of spatial autocorrelation analysis with Moran's Index method and Moran Scatter Plot of textile and textile products in Surakarta City resulted in index value of -0.0281203 . Hence, the index of industry is in the range of $\mathrm{I}<0 \leq 1$, with the moran value is negative it can be seen that the industry is spreading uneven territory and not spatially interconnected, it can be understood because Surakarta has textile industry units in various scales, for large-scale textile industries generally spread randomly, whereas small-scale industries identified tend to be more clustered. The spread of this sector identified at Banyuanyar, Sumber and Manahan at Banjarsari district and Jajar and Karangasem at Laweyan Subdistric, all of them located in diference circumstant who drived by textile production area.

The results of spatial cluster analysis in Figure 7 illustrate the location with the labor concentration level of the textile and textile products industry in Surakarta City. The areas categorized with high labor clusters include Jajar and Sumber, while those with the low labor clusters are Sriwedari, Jayengan, Kampung Baru, Kepatihan Kulon and Wetan. Based on data from BPS Surakarta, Jajar and Sumber are the producers of textile and its derivatives where there are numbers of garment entrepreneurs at various scales. In these areas, the contribution of the textile industry to the income and employment is huge, particularly in the absorption of uneducated female labors.

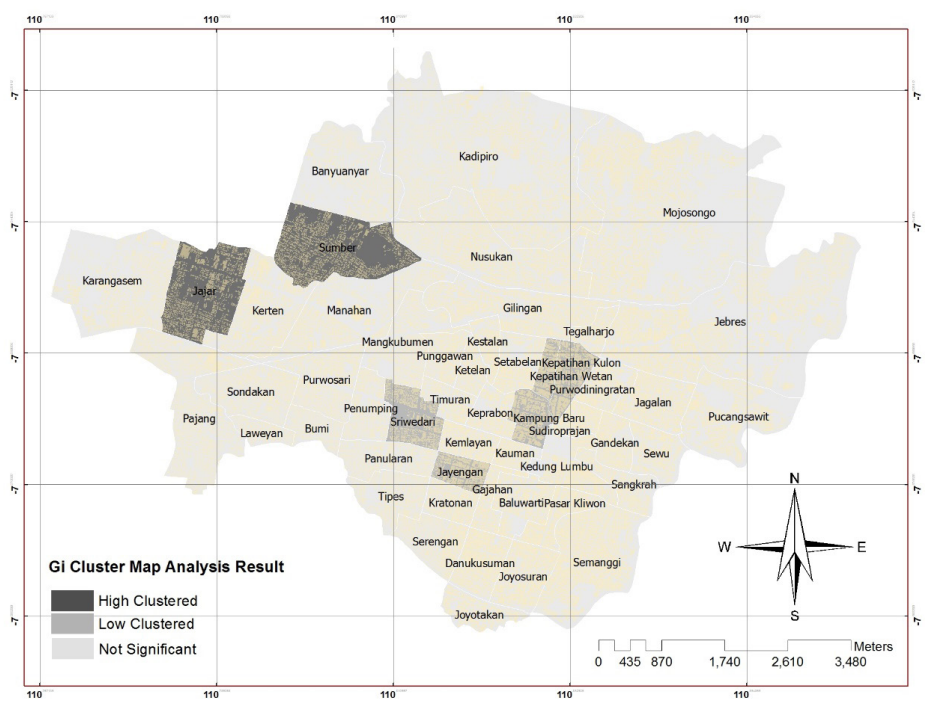

Figure 7. Local Spatial Autocorrelation of Textiles and Textile Products Map Cluster

\subsection{Garment Industry in Surakarta City}

The garment industry has been the backbone of economic and trade activities in Surakarta City for centuries. This industry is not merely a leading industry but also a prima donna and benchmark of Surakarta. The mainstay product of this sector is batik as demonstrated in Table 3 , this industrial sector has capacity to generate high added value of $\mathrm{Rp} 941,787,902,000$. 


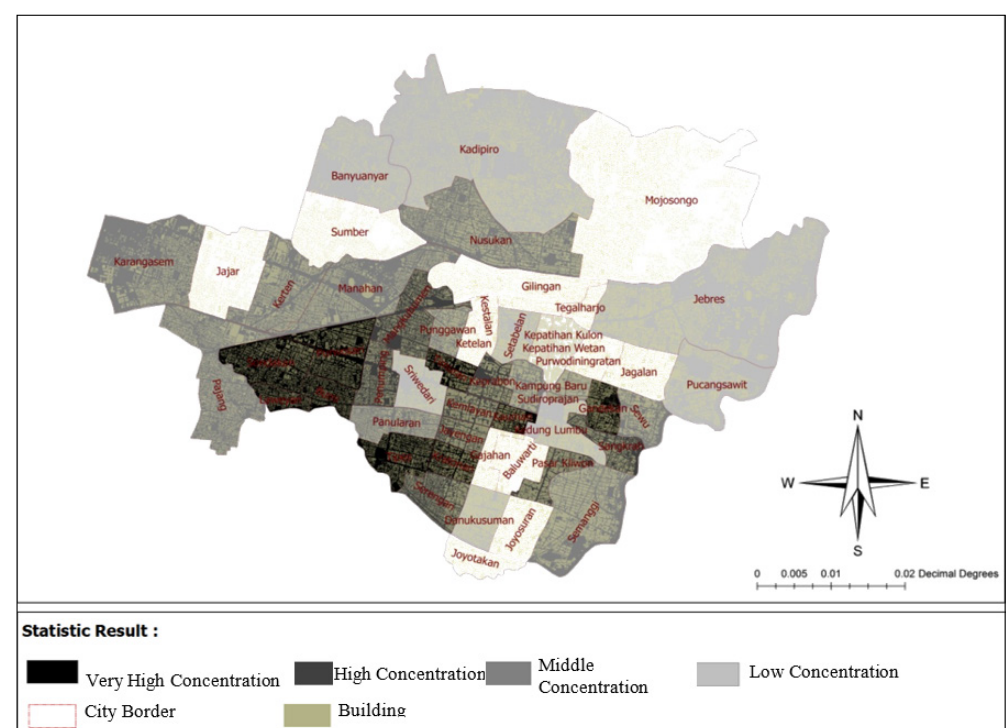

Figure 8 Spatial Concentration of Garment Industrial Units in Surakarta City

Garment industry centers are growing rapidly in line with the increasingly popular products of this sector. Figure 6 shows the clustering pattern of the garment units in Surakarta seems to center on several points in the southern part of Surakarta City, where concentration of garment units is in Laweyan Sub-district with four points; Laweyan, Sondakan, Pajang, and Bumi as the highest concentration in Laweyan. Centralization of industrial units also occurs in Pasar Kliwon Sub-district covering Desa Kauman, Sangkrah, and Semanggi as well as Serengan centered in Tipes.

\subsection{Moran's Index, Moran Scatter Plot and Local Spatial Autocorrelation of Garment Industrial Sector in Surakarta City}

Spatial autocorrelation with analysis of Moran's Index and Moran Scatter Plot explicates that the value of garment industry in Surakarta City is 0.143071 , thus this value is in the range of $0<\mathrm{I} \leq 1$, meaning that the garment industry in Surakarta City has low spatial correlation value.
Based on Moran Scatter Plot, the autocorrelated regions are located in several areas of Laweyan, Serengan and Pasar Kliwon Sub-districts. The Moran Scatter Plot analysis also describes that most of labor of garment industry in Surakarta City is concentrated in Quadrant II, it is indicates that there is a knowledge spillover on the users of labor in the areas included in quadrant II, in other words, there is a large-scale industrial labor share (high observation) towards the small-scale garment industry (low observation) or otherwise.

Based on the results of LISA analysis on the labor concentration of garment industry in Surakarta City, it can be explained that areas with high category clusters are centered in two subdistric they are Laweyan, covering Pajang, Purwosari, Sondakan, Laweyan and Bumi. The second one is located in Serengan sub-district covering Tipes, Kratonan, Kemlayan and Jayengan. Based on this result its can explain that Surakarta have local cluster in Textile sector who located in laweyan sub-district and supported by Serengan sub-district. 


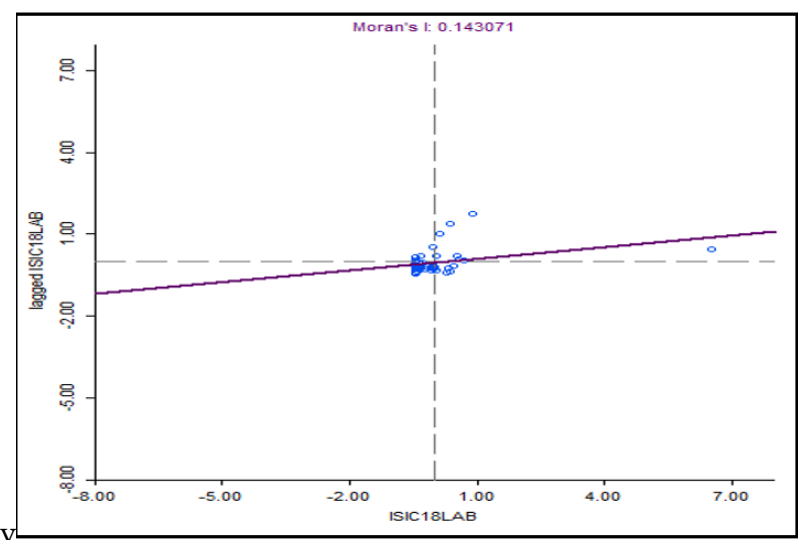

Diagram 3 Moran's Index and Moran Scatter Plot of Garment Industry in Surkarta

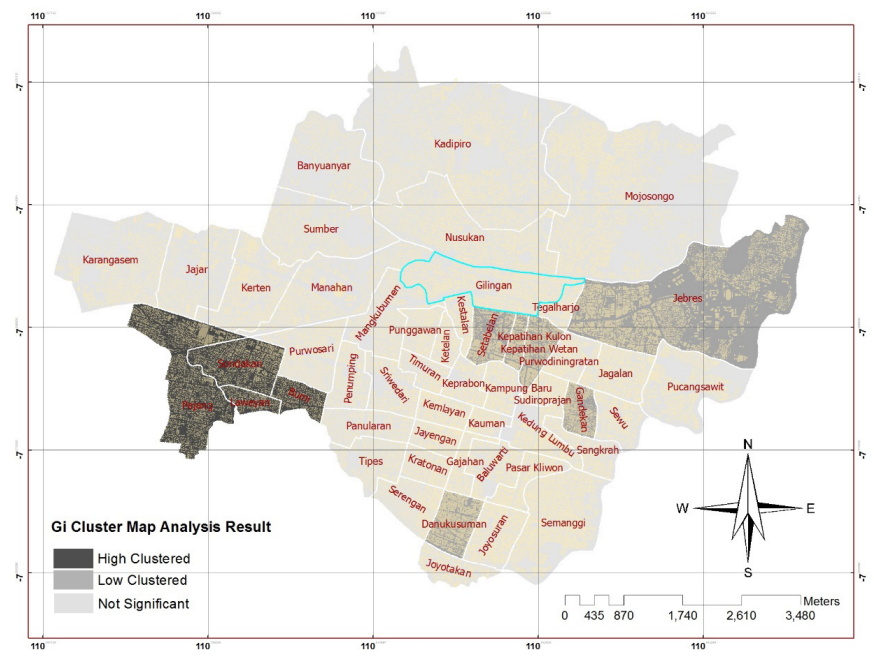

Figure 9. Local Spatial Autocorrelation of Textiles and textile products Map Cluster

Therefore, based on the analysis of geographical concentration on industrial unit, Moran's Index and LISA in accordance to the number of labor, it can be concluded that the garment industry in Surakarta City has formed cluster or center pattern, both in terms of unit and employment. Laweyan is the sub-district with the highest concentration of industrial units and is identified as the region with the highest labor clusters in Surakarta City, thus there is show that garment industry in Surakarta City is concentrated in this area. From the high contribution of this sector, it stated that garment industry is dominant in the regional revenue, thus appropriate regulation to manage the sustainability of this industry is required.

\subsection{Publishing, Printing and Local Spatial Autocorrelation Reproduction Industries}

The Publishing, Printing and Reproduction Industry is an industry with a very wide range and workflow scope, even though this industry can be simply defined as an industry that has a set of economic activities related to the creation or use of knowledge and information (Hesmondhalgh, 2007). The development of publishing, printing and reproduction industry in Surakarta is greatly 


\section{Jurnal Ekonomi Pembangunan, 18 (1), 2017, 64-81}

affected by the involvement of the socio-cultural conditions of Surakarta, the role of Surakarta as the city of culture and education definitely has immense impact in the development of this sector. The results of the spatial concentration analysis of this industry as illustrated in Figure 10, describe the dispersed conditions in all areas of Surakarta City, which indicates the absence of centers or clusters. Figure 10 demonstrates that the largest number of industries is located in Sudiroprajan, which is correlated to Kedung Lembu and Kampung Baru. Relatively high concentrations also occur in Tegalharjo supported by Desa Gilingan, while other areas are categorized in moderate to very low concentrations.

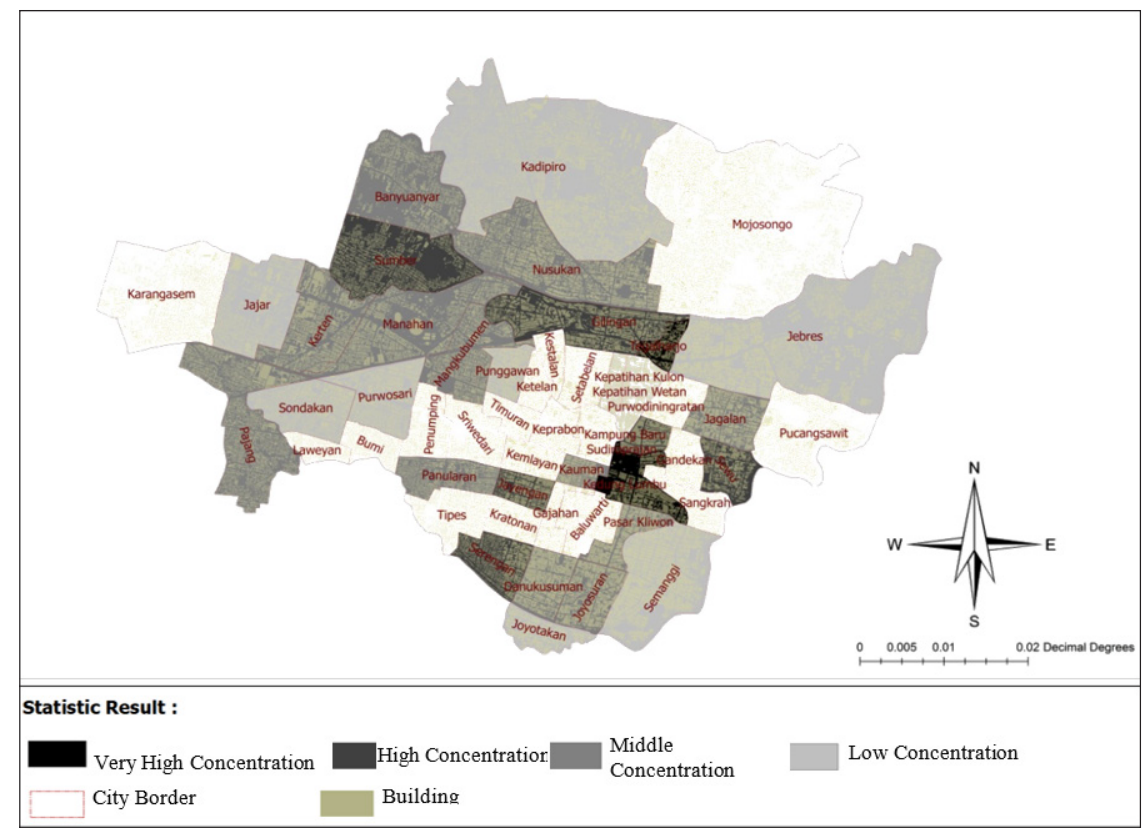

Figure 10. Spatial Concentration of Publishing, Printing, and Reproduction Industry in Surakarta City

3.11 Moran's Index, Moran Scatter Plot and Local Spatial Autocorrelation of Publishing, Printing, and Reproduction Industry in Surakarta City

Labor spatial concentration index of this sector has been analyzed by using Moran's Index and Moran Scatter Plot. The result of the analysis is Moran's index of 0.110081, which is in the range of $0<\mathrm{I} \leq 1$. Statistically, it indicates that the publishing, printing and reproduction industry in Surakarta City has low concentration. As the result of Moran Scatter Plot categorizes 3 (three) sub-districts included in high observation area, namely Pasar Kliwon,
Jebres and Banjarsari where they are spatially correlated to one another.

Spatial autocorrelation of labor in this sector as demonstrated by the results of LISA analysis in Figure 8, indicates that there are 2 (two) sub-districts with high labor cluster criteria, namely Banjarsari Sub-district (Manahan and Nusukan) and Jebres Sub-district (Tegalharjo). In accordance to the results, it interpreted that this industrial sector does not indicate the high concentration of labor as implied by the analysis results. In other words, this sector does not absorb labor as much as other sectors in which it is the capital-intensive industry that employs modern technology or machinery instead of human capital. 
Jurnal Ekonomi Pembangunan, 18 (1), 2017, 64-81

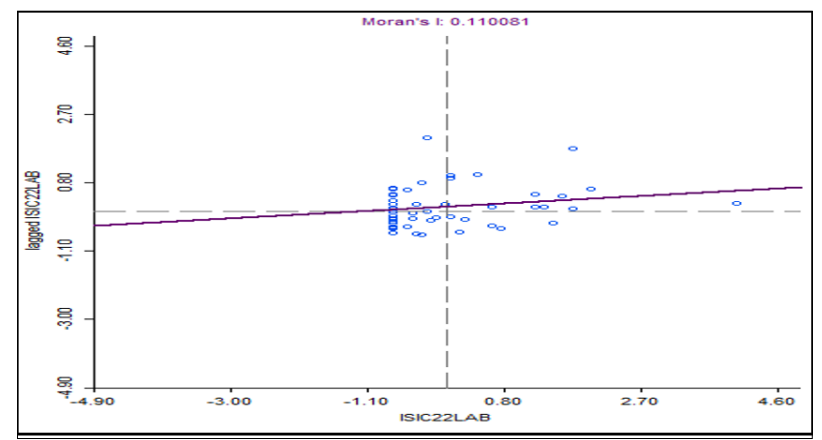

Diagram 4 Moran's Index and Moran Scatter Plot of Publishing, Printing, and Reproduction Industry in Surakarta City

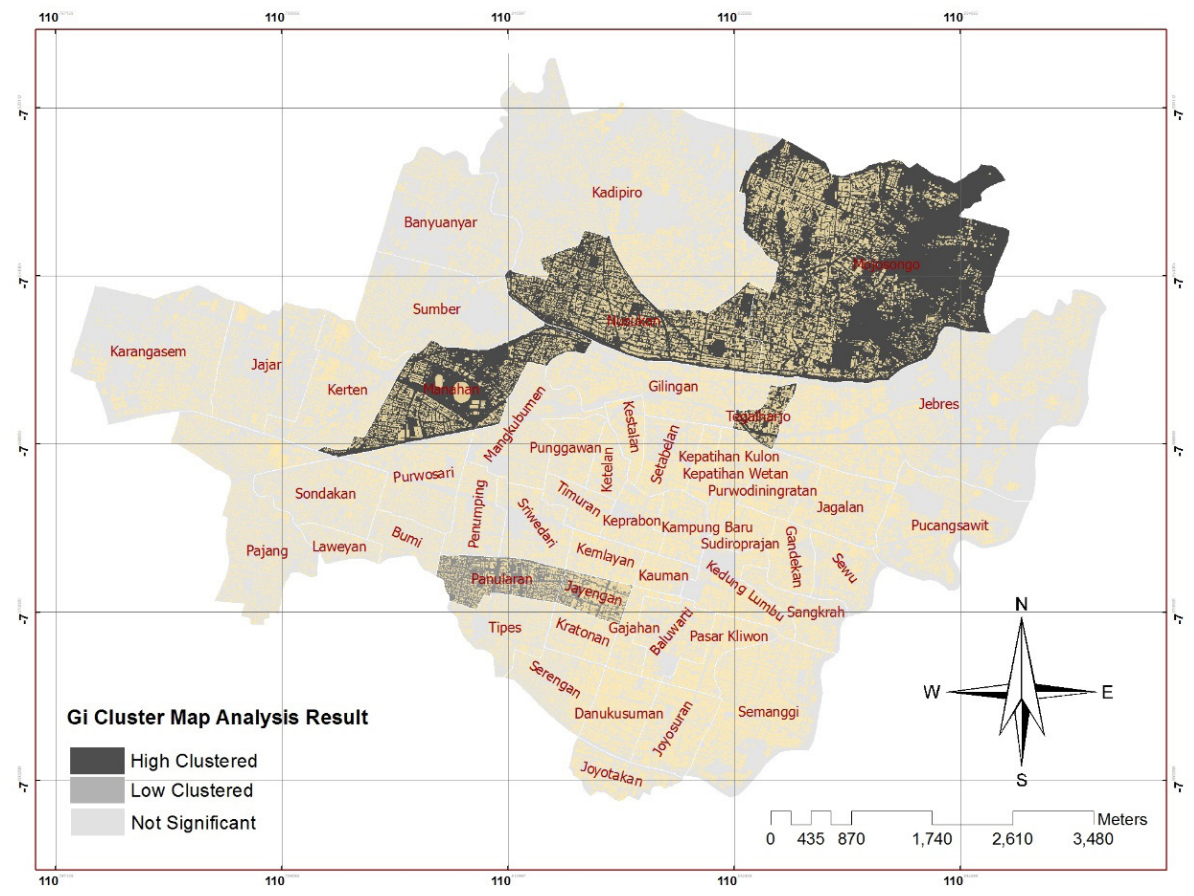

Figure 11. Local Spatial Autocorrelation of Publishing, Printing, and Reproduction Industry Map Cluster

\subsection{Furniture and Other Manufacturing}

The last leading industry based on analysis in this study is the furniture and other manufacturing industries. Surakarta City has a variety of furniture industries which become the superior products at regional scale, although they are slightly different with furniture center in Central Java, where most of the products are intended for artistic furniture in the form of decoration and creative industries based on wood and its derivatives. The spatial analysis of furniture and other manufacturing unit units as shown in Figure 12, describes there are some high concentration points, which means the area is spatially location where there are many producers that produce furniture and other manufacturing products in Surakarta City. They include Jebres and Joyotakan. At the lower scale concentration of industrial units, Kadipiro, Gilingan and Sriwedari are also identified as the producers of creative industries based on wood and derivatives that become vital asset of Surakarta City. 
Jurnal Ekonomi Pembangunan, 18 (1), 2017, 64-81

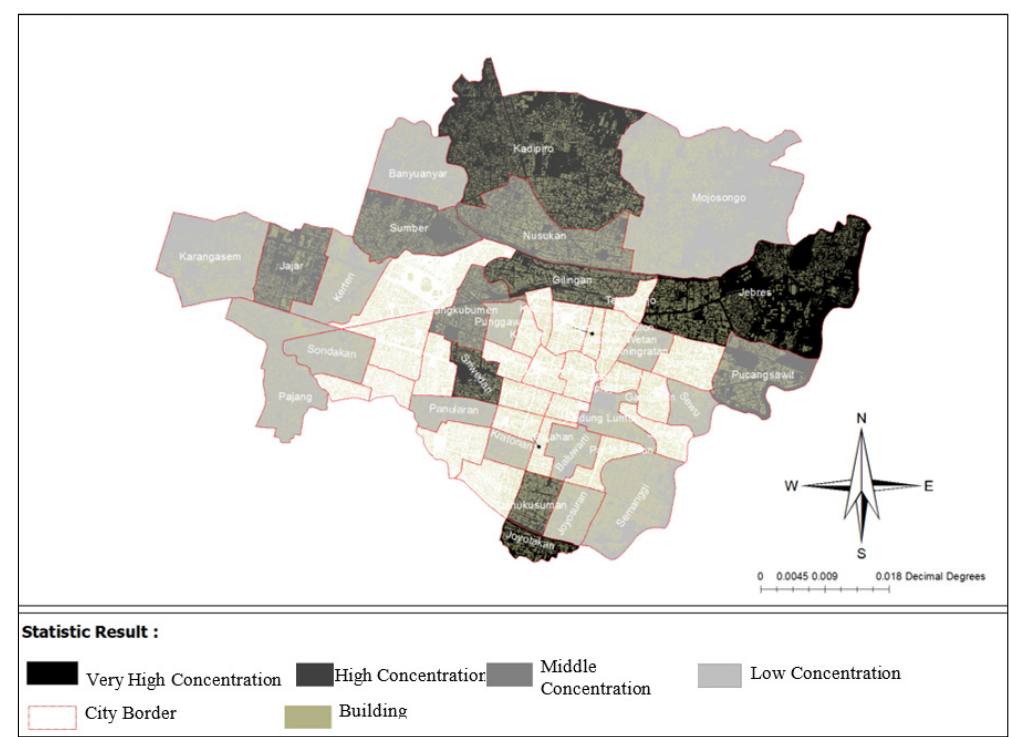

Figure 12. Spatial Concentration of Furniture Industry and Other Manufacturing Units

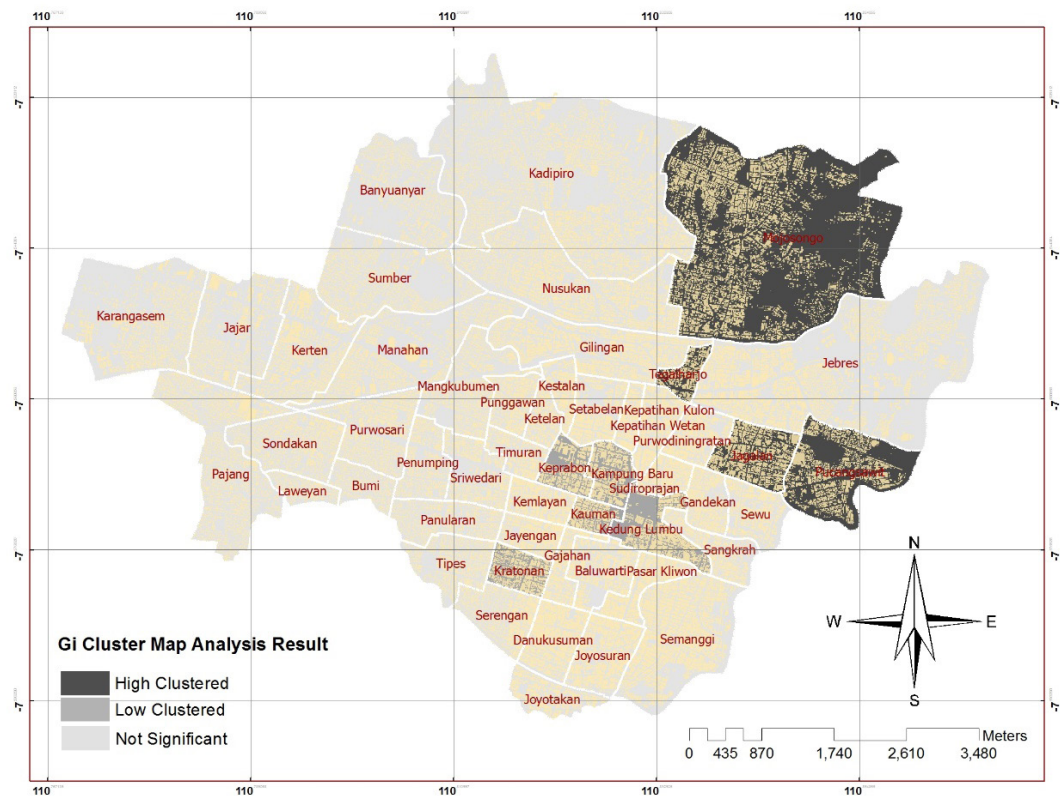

Figure 13. Local Spatial Autocorrelation of Furniture Industry and other Manufacturing Map Cluster

3.13 Moran's Index, Moran Scatter Plot City is 0.0747813 , meaning there is a very low and Local Spatial Autocorrelation correlation among the labor users in this sector. of Furniture Industry and Other Moran Scatter Plot explicates that the area with Manufacturing in Surakarta City high observation are: Kadipiro, Banyuanyar, Based on Moran's index, the labor spatial Nusukan and Gilingan in Banjarsari Sub-district; concentration of furniture industry in Surakarta and Danukusuman in Serengan Sub-district. 


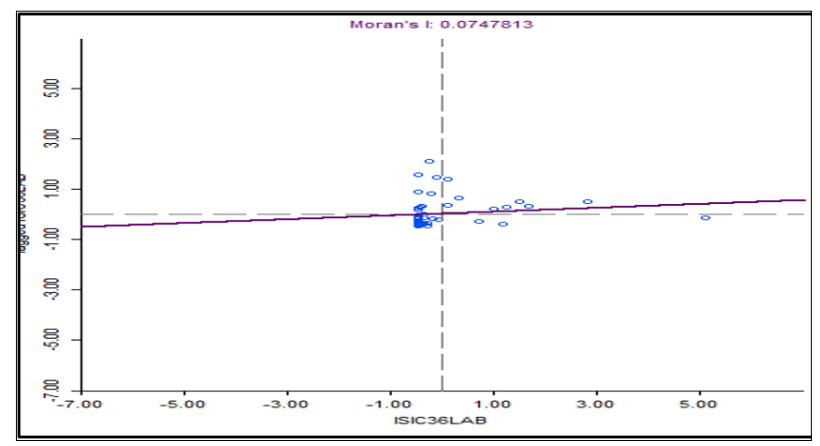

Diagram 5 Moran's Index and Moran Scatter Plot of Furniture Industry and Other Manufacturing in Surakarta City

Based on LISA, Mojosongo, Tegalharjo, Jagalan and Pucangsawit are categorized in clusters with high observation, while Keprabon, Kampung Baru, Sudiroprajan, Gandekan, Kauman, Kedung Lumbu and Kratonan have low cluster values. However, the result of Moran's index $(0,07478)$ indicates that this sector has very low regional autocorrelation, or there is almost no territorial relationship among regions.

\section{Conclusions}

Basically, the Exploratory Spatial Data Analysis (ESDA) approach was employed in this study. Furthermore, it was divided into three categories based on the objectives that had been determined at the beginning of the discussion. For the first objective, it is known that the concentration spatial pattern of the leading industries in Surakarta tends to be away from the downtown where the clusters are built in the west part of the city. The second objective, the spatial autocorrelation among the observed areas as the basis in finding the leading industrial clusters showed the relatively low cluster (less than 0.5) based on Moran's index analysis. It indicates those clusters were formed due to the reaction of market participants who take benefit from location advantage to set up their business units. However, there is an absence of scheme to create a complex cluster for leading industries.

This stage also revealed the sector with negative Moran's index, namely the textile and textile product this score explain that textile and textile product industry spreads unevenly and have no spatial autocorrelation. It is appear be due to the textile industry units in Surakarta range from a variety of scales, for large-scale textile industries are generally dispersed in random pattern on the other hand small-scale industries tend to be more clustered. In the third stage, the concentration of economic clusters is explained through LISA, the results of analysis indicate that the food and beverages industry has cluster pattern with the point in Kelurahan Pajang, Laweyan Sub-district. In the textile and textile products industry, the areas categorized as having high labor clusters include Jajar and Sumber. Garment industry has the highest Moran's index among other sectors, the industry is identified to have a cluster pattern both in terms of unit and labor absorption. It revealed Laweyan Sub-district as the area that has the highest concentration of industrial unit as well as the highest labor clusters in Surakarta City. Hence, the there is possibility the garment industries are concentrated in this area. The printing industry has identified two sub-districts with high labor cluster criteria, namely Banjarsari Sub-district (Manahan and Nusukan) and Jebres Sub-district (Tegalharjo). Finally, the clusters of furniture and other manufacture industry are identified in Mojosongo, Tegalharjo, Jagalan and Pucangsawit that are categorized in high observation clusters, while Keparabon, Kampungbaru, Sudiroprajan, Gandekan, Kauman, Kedung Lumbu and Kratonan had low cluster values.

In overall, based on the regional aggregate scale (Surakarta City), the areas with the highest 


\section{Jurnal Ekonomi Pembangunan, 18 (1), 2017, 64-81}

concentration of labor absorption identified at Jebres and Mojosongo in Jebres Sub-district as well as Pajang and Sondakan in Laweyan Subdistrict.

\section{References}

Anselin, L. (2003). GeoDa ${ }^{\mathrm{TM}} 0.9$ User's Guide. Design, 126. Retrieved from http://www.unc. edu/ emch/gisph/geoda093.pdf

Anselin, L., Syabri, I., \& Kho, Y. (2006). An Introduction to Spatial Data Analysis. Geographical Analysis, 38, 5-22. https://doi. org/10.1111/j.0016-7363.2005.00671.x

Arif, M., \& Soeratno. (2015). Perkembangan Spasial Penggunaan Lahan Real Estat dan Pengaruhnya terhadap Perekonomian Kota Surakarta. Retrieved March 7, 2016, from https://publikasiilmiah.ums.ac.id/bitstream/ handle/11617/6863/2nd Urecol - Muhammad Arif.pdf? sequence $=1 \&$ isAllowed $=\mathrm{y}$

Arif, M., \& Utomo, Y. P. (2016). Konsentrasi Spasial Industri Industri Unggulan Kota Surakarta. In The 3rd University Research Colloquium (URECOL) (pp. 35-53). LPPM STIKES Muhammadiyah Kudus. Retrieved from http://publikasiilmiah.ums.ac.id:80/ handle/11617/6710

Berdahl, R. M., Cohon, J. L., Simmons, R. J., Leslie, W., Berlowitz, C., \& Sexton, J. (1997). The University and the City. GeoJournal, 41(4), 301-309.

Deichmann, U., Lall, S. V., Redding, S. J., \& Venables, A. J. (2008). Industrial location in developing countries. World Bank Research
Observer, 23(2), 219-246. https://doi. org/10.1093/wbro/lkn007

Friedmann, J. (2005). Globalization and the emerging culture of planning. Progress in Planning, 64(3), 183-234. https://doi. org/10.1016/j.progress.2005.05.001

Hesmondhalgh, D. (2007). The Cultural Industries (2nd ed.). New York: SAGE Publications.

Krugman, P. (1991). Increasing Returns and Economic Geography. The Journal of Political Economy, 99, 483-499. https://doi. org/10.1086/261763

Kuncoro, M. (2000). The Economic of Industrial Aglomeration and Clustering, 1976-1996: the Case of Indonesia (Java). University of Melbourne.

Smith, M. J. de, Goodchild, M. F., \& Longley, P. A. (2015). Geospatial Analysis: A Comprehensive Guide to Principles, Techniques and Software Tools. Retrieved from http://www.spatialanalysisonline.com/ HTML/?conceptual_frameworks_for_spat. $\mathrm{htm}$

Wheeler, J. O., \& Muller, P. O. (1986). Economic Geography. New York: Jhon Wiley \& Sons.

Yang, Z., Hao, P., \& Cai, J. (2015). Economic clusters: A bridge between economic and spatial policies in the case of Beijing. Cities, 42(PB), 171-185. https://doi.org/10.1016/j. cities.2014.06.005

Yunus, H. S. (2000). Struktur Tata Ruang Kota. Yogyakarta: Pustaka Pelajar. 